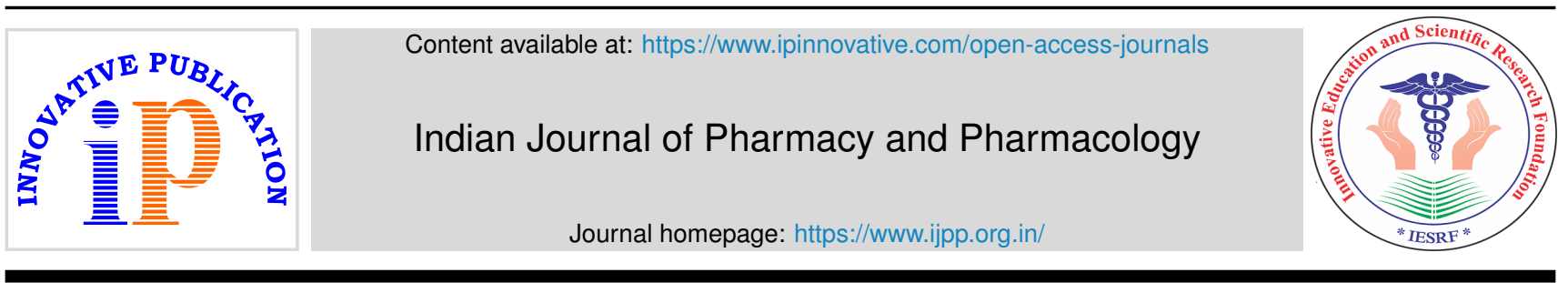

Original Research Article

\title{
A questionnaire based cross sectional study to assess the knowledge and perceptions regarding concept of rational use of medicines among second year medical students
}

\author{
Harish G Bagewadi ${ }^{1}$, Priyadarshini M Deodurg ${ }^{1}$, Syed Wasif ${ }^{1, *}$ \\ ${ }^{1}$ Dept. of Pharmacology, Gulbarga Institute of Medical Sciences, Gulbarga, Karnataka, India
}

\section{A R T I C L E I N F O}

Article history:

Received 08-10-2020

Accepted 12-01-2021

Available online 19-04-2021

Keywords:

Rational use of medicines

Knowledge

Perceptions

\begin{abstract}
A B S T R A C T
Background: The main goal of teaching clinical pharmacology, concept of rational usage of medicines to medical students is to imbibe the knowledge, skills so that in future as a clinicians they will be able to weigh the potential benefits versus risks of a treatment along with its cost-effectiveness.

Objective: To assess the knowledge, attitude and perceptions about rational use of medicines in second year medical students.

Materials and Methods: This was a questionnaire -based, cross-sectional study. The study participants were second year medical students (152). The questionnaire was designed to assess the knowledge, perceptions about rational usage of medicines.

Results: Were expressed as counts and percentages. Majority of respondents were aware about over the counter medicines $(72 \%)$, importance of reading medicine label $(86 \%)$. Majority of the students $84 \%$ purchased all medicines written in prescription.

Conclusion: Majority of the students were aware about the concept of rational usage of medicines which seems to be a positive finding.

(C) This is an open access article distributed under the terms of the Creative Commons Attribution License (https://creativecommons.org/licenses/by/4.0/) which permits unrestricted use, distribution, and reproduction in any medium, provided the original author and source are credited.
\end{abstract}

\section{Introduction}

For the highly efficient health care system to be functional the key parameters are its access, cost effectiveness and rational use of medicines. ${ }^{1}$ Rational use of medicines encompasses the patients receive drugs appropriate for their clinical needs, in correct doses that meet their own individual requirements, for an adequate period of time and cost effective treatment for both the patients and community. ${ }^{2}$ False beliefs, improper knowledge among patients, prescribing pressures, money driven approach of prescribers, pharmaceutical industries lucrative promotional biases, less rigorous monitoring by regulatory agencies all will pay the way for irrational prescribing habits. ${ }^{3}$ There by leading to the gross wastage of resources, more adverse drug reactions, development of antibacterial resistance, increase

\footnotetext{
* Corresponding author.

E-mail address: drsyedwasif@gmail.com (S. Wasif).
}

in treatment costs which all can be prevented by leaps and bound by enforcing the concept of rational usage of medicines among the doctors and health care professionals. To counter the malpractice of irrational prescribing, the idea remains in the fact that first it needs to be measured and made accountable to the concerned heath care professionals. Development of yardstick for its measurement is essential to bring focused, effective, rational prescribing habits into practice. The important stakeholders are identified like nurses, pharmacy students, pharmacists, prescribers and many previous studies have assessed the knowledge, attitude, perceptions of these stake holders about rational use of medicines. ${ }^{4}$ As medical students are budding future doctors, it is very essential to impart the concept of rational use of medicines in their early learning phases so that good habits are inculcated. In the current medical curriculum, teaching is more focused on symptoms and making 
correct diagnosis and little attention is paid for imbibing the concepts, skills required for the rational usage of medicines. ${ }^{5}$ The interns who are budding doctors needs to be more skilled in rational prescribing methods. The WHO six steps of rational prescribing are an important guide to prepare UG doctors in the approach of rational prescribing. For the correct approach of rational prescribing, WHO has given the six steps to be followed to doctors. The steps are to be followed sequentially. 1: Define the patient's problem correctly 2: Specification of the therapeutic objective 3: suitability of $\mathrm{P}$ drug is chosen appropriately 4: Write the prescription legibly and correctly 5: Give the instructions and warnings to the patient appropriately 6: Timely monitor or stop the treatment. A study was conducted in Nigeria on the prescribing knowledge in interns. ${ }^{6}$ It demonstrated the deficiencies in UG pharmacology teaching, and concluded that medical students and interns should be periodically assessed on prescribing knowledge and skills during their training as a means of minimizing prescribing errors. Hence, evaluating the medical students knowledge in rational usage of medicines in this regard is very essential. Many previous studies have assessed the knowledge, perceptions of health care professionals about self-medication. ${ }^{7-9}$ Various interventional projects have been tried meticulously to revitalize the rational prescribing habits of medical students by adopting skillful, measurable methods. ${ }^{10,11}$ This present study was conducted to evaluate the knowledge, perceptions about rational use of medicines among medical students.

\section{Materials and Methods}

This was a questionnaire based, cross-sectional study. The permission to conduct the study was dully approved by the from Institutional Ethics Committee prior to the start of the study. Our study population included 152 students of $2^{\text {nd }}$ year medical students of Gulbarga institute of medical sciences, Kalaburagi. The students were briefed about the study and their consent was taken. Care was taken not to disclose the identity of the study participants. The study questionnaire consisted of a pre-validated, semi-structured, open-ended and closed-ended items. The questionnaire was obtained from the similar previous study done by Sontakke SD et al. ${ }^{12}$ Slight modifications were done in our study as per the subject experts opinion. Questionnaire was designed to obtain information about various issues concerned with rational use of medicines. The final version of the questionnaire was distributed to the medical students. Statistical analysis: Data was expressed as counts and percentages. Graph pad prism software version 5.01 was used to analyze data.

\section{Results}

It was evident from the (Table 1) that majority of the students were aware about over the counter medicines
$(72 \%)$, and believed that it is not safe to take over the counter medicines with prescription medicines (92\%). Majority were also aware that same generic content of medicines is available under different names (84\%) and there is variation in the prices of different brands of the same medicine $(68 \%)$. It was seen that only $32 \%$ students opined that any tablet can be divided for use in pediatric patients.

It was observed from the (Table 2) that very few students believed that costlier medicines are better than cheaper ones $(16 \%)$ and medicines manufactured by multinational companies are better $(10 \%)$. About $65 \%$ of the students believed that more number of medicines in the given prescription, better is the outcome of the treatment effects. Majority of the students $98 \%$ opined that medicines from government hospitals are in par when compared to those from private pharmacies. It is interesting to note the majority of the students $(88 \%)$ opined that doctors should not blindly believe on information about drugs provided by medical representatives from company.

From the (Table 3) it shows that $86 \%$ respondents read label on over the counter medicines before use. Very few respondents (4\%) admitted that they reused doctor's prescription for similar complaint in other person, purchased any medicines online (12\%). Majority of the students $77 \%$ are aware that central drugs control standard organization advises doctors to prescribe only generic drugs and $95 \%$ consulted the doctor before stopping medicine.

\section{Discussion}

National Rural Health Mission in agreement with WHO insists that the concept of rational usage of drugs should be nested in the minds of young budding doctors and should be thought and enforced in the under graduate medical curricula. ${ }^{1}$ Students in their early their learning stage, they are most vulnerable to getting influenced by many factors which can affect their perception either positively or otherwise. Our study evaluates knowledge, perceptions about rational use of medicines in second year medical students. $72 \%$ of the students believed that over the counter medicines can't be safely taken with concomitant prescribed drugs. It is advisable that any over the counter medicines medicine should be taken only after consulting the doctor.

It was observed that $(32 \%)$ of the students opined that any tablet can be broken into parts for use in pediatric patients. This unawareness may be explained by the fact that the second year medical students they still have not yet completed their bed side clinical postings. Majority of the $68 \%$ of students were are aware that wide variation in costs of different brands of same drug is available in the market. Our study observations are similar in accordance with previous study done by Sontakke SD et al. ${ }^{12}$ It is very crucial that these concepts remain in students minds, it is possible only when all these issues are repeatedly reinforced upon them and they are made to realize the 
Table 1: Evaluation of respondents' knowledge about rational use of medicines $(n=152)$

\begin{tabular}{|c|c|c|}
\hline S. No. & Items & Respondents (\%) \\
\hline 1 & Aware about over the counter medicines & $\begin{array}{l}\text { Yes }-72 \% \\
\text { No }-28 \%\end{array}$ \\
\hline 2 & $\begin{array}{l}\text { Over the counter medicines can be safely taken along with prescribed } \\
\text { medicines }\end{array}$ & $\begin{array}{l}\text { Yes }-08 \% \\
\text { No }-92 \%\end{array}$ \\
\hline 3 & $\begin{array}{l}\text { Aware that same generic content of drug is available with different brand } \\
\text { names }\end{array}$ & $\begin{array}{l}\text { Yes- } 84 \% \\
\text { No }-16 \%\end{array}$ \\
\hline 4 & $\begin{array}{l}\text { Aware that there exists marked variation in costs of different brands of } \\
\text { same drug }\end{array}$ & $\begin{array}{l}\text { Yes }-68 \% \\
\text { No }-32 \%\end{array}$ \\
\hline 5 & $\begin{array}{l}\text { Aware about special precautions are needed to be taken in children before } \\
\text { drug administration }\end{array}$ & $\begin{array}{l}\text { Yes }-84 \% \\
\text { No }-16 \%\end{array}$ \\
\hline 6 & $\begin{array}{l}\text { Aware about special precautions are needed to be taken in in pregnant and } \\
\text { breastfeeding women before drug administration }\end{array}$ & $\begin{array}{l}\text { Yes }-90 \% \\
\text { No }-10 \%\end{array}$ \\
\hline 7 & Aware about precautions to be taken while using drugs in elderly patients & $\begin{array}{l}\text { Yes }-78 \% \\
\text { No }-22 \%\end{array}$ \\
\hline 8 & $\begin{array}{l}\text { I believe that any tablet can be divided into smaller parts for use in } \\
\text { pediatric patients }\end{array}$ & $\begin{array}{l}\text { Yes }-32 \% \\
\text { No }-68 \%\end{array}$ \\
\hline 9 & Aware about expiry date of drugs & $\begin{array}{l}\text { Yes }-98 \% \\
\text { No }-02 \%\end{array}$ \\
\hline
\end{tabular}

Table 2: Evaluation of respondents' attitude about rational use of medicines $(n=152)$

\begin{tabular}{llc}
\hline S.No. & Items & Respondents (\%) \\
1 & Costlier medicines are better than cheaper ones & Yes $-16 \%$ \\
& & No $-84 \%$ \\
2 & Medicines manufactured by foreign multinational companies are better & Yes $-10 \%$ \\
& & No $-90 \%$ \\
3 & More the number of medicines in a prescription better \& earlier will be the relief & Yes $-65 \%$ \\
4 & Medicines from government hospitals are in & No $-35 \%$ \\
& par to those from private medical shops & Yes $-98 \%$ \\
5 & Doctors can completely depend on information about drugs given by pharma & No $-02 \%$ \\
& industries. & Yes $-12 \%$ \\
\end{tabular}

Table 3: Evaluation of perceptions of rational use of medicine $(n=152)$

\begin{tabular}{|c|c|c|}
\hline S.No. & Items & Respondents (\%) \\
\hline \multirow{2}{*}{1} & \multirow{2}{*}{ I always read label on over the counter medicines before use. } & Yes $-86 \%$ \\
\hline & & No $-14 \%$ \\
\hline \multirow{2}{*}{2} & \multirow{2}{*}{ Do you reuse doctor's prescription for similar complaint in other person } & Yes $-04 \%$ \\
\hline & & No $-96 \%$ \\
\hline \multirow{2}{*}{3} & \multirow{2}{*}{ Purchase any medicines Online } & Yes- $12 \%$ \\
\hline & & No $-88 \%$ \\
\hline \multirow{2}{*}{4} & \multirow{2}{*}{$\begin{array}{l}\text { Mixing up of the treatment of more than one doctors simultaneously for same } \\
\text { problem }\end{array}$} & Yes $-02 \%$ \\
\hline & & No $-98 \%$ \\
\hline \multirow{2}{*}{5} & \multirow{2}{*}{ Mix allopathic treatment with Ayurvedic/ traditional /homeopathy/ } & Yes $-22 \%$ \\
\hline & & No $-78 \%$ \\
\hline \multirow{2}{*}{6} & \multirow{2}{*}{ Purchase all medicines written in prescription } & Yes $-84 \%$ \\
\hline & & No $-16 \%$ \\
\hline \multirow{2}{*}{7} & \multirow{2}{*}{$\begin{array}{l}\text { I am aware that central drugs control standard organization advises doctors to } \\
\text { prescribe only generic drugs. }\end{array}$} & Yes $-77 \%$ \\
\hline & & No $-23 \%$ \\
\hline \multirow{2}{*}{8} & \multirow{2}{*}{ Consult the doctor before stopping medicine } & Yes $-95 \%$ \\
\hline & & No $-5 \%$ \\
\hline
\end{tabular}


consequences of irrational prescribing. In our study majority of the students agreed that doctors should not blindly believe on information about drugs given by pharmaceutical industry. The irrational prescribing habit leads to leaps and bound gains to pharmaceutical companies. This menace of irrational drug prescribing can be put into halt only when the young doctors are self-motivated, more goal oriented towards the better outcome of the patient. Reminding the medical students about this by way of appropriate inclusions in the medical curriculum repeatedly can help the students to keep vigil on this art of prescribing. Another positive finding in our study was that the majority of students opined for prescribe only generic drug by the physicians (65\%). Our study results are similar in accordance with previous study done by Naik M et al. ${ }^{13}$ Previous study by Cameron et al. ${ }^{14}$ highlighted the major concerns with the generic prescribing in developing countries. It is very vital that the WHO stepby-step guide to prescribing be included as a part of UG training and reinforced during the training of internship and future prescribers thereafter. $23 \%$ of the respondents are not aware that central drugs control standard organization advises doctors to prescribe only generic drugs. This needs to be addressed since prescribing medicines by generic names is an important measure for the implementation of rational usage of medicines policies. Irrational prescribing trends leads to major cause of errors in prescribing with its adverse consequences subsequently. ${ }^{15}$

Our limitation in this study is it was conducted over short period of time and less number of participants. Our strength in this study is we could explore the gap in the knowledge of the students regarding rational usage of medicines and could identify the knowledge gaps. Multicenter study with larger samples will be beneficial. Repeated studies and assessments of subsequent batches of interns will be required.

\section{Conclusion}

Majority of students were aware about various issues concerned with rational use of medicines.

Vigil is to be kept over the measures promoting irrational prescribing trends and through efficient training of undergraduate medical students should be inculcated in their curriculum to dexterity the skill of rational usage of medicine among budding doctors.

\section{Conflict of Interest}

The authors declare no conflict of interest.

\section{Acknowledgement}

The authors would like to thank all the second year medical students for their active participation in the study.

\section{References}

1. Sharma S. Promoting Rational drug use under National Rural Health Mission, National Health Resources centre. Ministry of Health and Family Welfare, Government of India ; 2009.

2. World Health Organisation: Guide to Good Prescribing, Geneva. World Health Organisation; 1994.

3. Holloway K. Promoting rational use of medicines. Contact a publication of world council of churches; 2006.

4. Toklu HZ, Demirdamar R, Gümüşel B, Yarış EE, Dülger G. Rational drug use awareness of the nurses in the turkish republic of northern cyprus near east university hospital. Marmara Pharm J. 2012;16:150 4.

5. World Health Organization. Guide to Good Prescribing - A Practical Manual. Available from: http://apps.who.int/medicinedocs/en/d/ Jwhozip23e/(lastaccessedon.

6. Oshikoya KA, Senbanjo IO, Amole OO. Interns' knowledge of clinical pharmacology and therapeutics after undergraduate and ongoing internship training in Nigeria: a pilot study. BMC Med Educ. 2009;9(1):50. 101:0/186/4/2-6920-9-50

7. James H, Handu SS, Khaja KA, Otoom S, Sequeira RP. Evaluation of the Knowledge, Attitude and Practice of Self-Medication among First-Year Medical Students. Med Princ Pract. 2006;15(4):270-5. 10:-10. $159 / 000022989$

8. James H, Handu SS, Khaja KA, Sequeira RP. Influence of medical training on self-medication by students. Int J Clin Pharmacol Ther. 2008;46(01):23-9. do1:10.5414/cpp46023.

9. Sontakke SD, Bajait CS, Pimpalkhute SA, Jaiswal KM, Jaiswal SR. Comparative study of evaluation of self-medication practices in first and third year medical students. Int J Biol Med Res. 2011;2(2):561-4.

10. Patrício KP, Alves NB, Arenales NG, Queluz TT. Teaching the Rational Use of Medicinesto medical students: a qualitative research. BMC Med Educ. 2012;12(1):56. 10ن:0. 186/472-6920-12-56.

11. De-Sousa F, Andressa B, Fernanda B, Fernandes MS. Rational use of medicines report of an experience in medical education at unesc criciúma, santa catarina state, brazil. Rev Bras Educ Med. 2010;34(3):438-45.

12. Sontakke S, Budania R, Paranjape S. Evaluation of knowledge, attitude and behavior about rational use of medicines in second year medical students. Int J Basic Clin Pharmacol. 2013;2(5):617-21. doi:10.5455/2319-2003.1]bcp20131019.

13. Naik M, Nerurkar R, Phatak A, Panchal S, Paunikar A. A questionnaire-based study to assess rational prescribing practice among interns. Natl J Physiol Pharm Pharmacol. 2015;5(4):323-7. doi:10.5455/nippp.2015.5.0605201549.

14. Cameron A, Mantel-Teeuwisse AK, Leufkens HGM, Laing RO. Switching from Originator Brand Medicines to Generic Equivalents in Selected Developing Countries: How Much Could Be Saved? Value Health. 2012;15(5):664-73. ब01:10.1016/].Jval.2012.04.004

15. Maxwell S, Walley T, Ferner RE. Using drugs safely. BMJ. 2002;324(7343):930-1.

\section{Author biography}

Harish G Bagewadi, Associate Professor

Priyadarshini M Deodurg, Professor and HOD

Syed Wasif, Assistant Professor

Cite this article: Bagewadi HG, Deodurg PM, Wasif S. A questionnaire based cross sectional study to assess the knowledge and perceptions regarding concept of rational use of medicines among second year medical students. Indian J Pharm Pharmacol 2021;8(1):88-91. 